\title{
PERILAKU BUDIDAYA PETANI MANGGA DIKAITKAN DENGAN LEMBAGA PEMASARANNYA DI KECAMATAN GREGED KABUPATEN CIREBON
}

\author{
${ }^{1}$ Mentari Nur Azizah, ${ }^{2}$ Elly Rasmikayati, ${ }^{2}$ Bobby Rachmat Saefudin \\ Fakultas Pertanian Universitas Padjadjaran, Jalan Raya Bandung - Sumedang KM 21 \\ Sumedang, 45363 \\ ${ }^{1}$ Mahasiswa Fakultas Pertanian Universitas Padjadjaran Tahun 2018 \\ ${ }^{2}$ Staf Pengajar Fakultas Pertanian Universitas Padjadjaran \\ email : mentari.azizah@gmail.com
}

\begin{abstract}
Greged Disrict was one of mango production center in Cirebon Regency, West Java. However the mango productivity still fluctuated and its distribution by farmers were still limited in certain marketing institutions. Purpose of the research was to describe mango farmers cultivation behavior related to the marketing institutions in Greged subdistrict, Cirebon Regency. Research design used was a quantitative research with survey method. Respondents in the research were 130 mango farmers that randomly chosen. Data analysis tools used were crosstab data analysisand descriptive statistical analysis. Result of study showed that marketing institutions chosen by farmers were farmer groups (2\%), middlemen (35\%), big sellers (51\%), traditional markets (9\%), and central markets (3\%). Most mango farmers with various marketing institutions addressed in Greged subdistrict had 1-2 labors from family and not family, apllied off-season technology, pest and diseases controlling used pesticides and pest traps, applied planting time settings, had yield results with grade $A$ and $B$ quality at ranges of 41-60\%, and the productivity per tree was 101-300 kg/tree. Farmers used their business garden lands and home garden yards to plant mango, except farmers that sold mangoes to central market they only used business garden lands. Farmers who sold their production results to farmer groups and central markets didn't wash the fruits, while most of farmers who sold to middlemen, big sellers, and traditional markets washed the fruits, sorting, grading, packaging, and labelling.
\end{abstract}

Keywords : Cultivation Behavior, Marketing Institutions, Mango Farmers.

\begin{abstract}
ABSTRAK
Kecamatan Greged merupakan salah satu sentra produksi mangga di Kabupaten Cirebon, Jawa Barat. Namun, produksi mangga tersebut berfluktuasi dan pendistribusian buah mangga yang dilakukan oleh petani masih terbatas di lembaga pemasaran tertentu. Tujuan penelitian ini adalah untuk mendeskripsikan perilaku budidaya petani mangga dikaitkan dengan lembaga pemasarannya di Kecamatan Greged, Kabupaten Cirebon. Desain penelitian yang digunakan adalah penelitian kuantitatif dengan metode survei. Responden dalam penelitian ini yakni 130 orang petani mangga yang diambil secara acak. Alat analisis data yang digunakan adalah analisis data crosstab dan analisis statistik deskriptif. Hasil penelitian menunjukkan bahwa lembaga pemasaran yang dipilih petani yaitu kelompok tani (2\%), tengkulak (35\%), bandar (51\%), pasar tradisional (9\%), dan pasar induk (3\%). Mayoritas petani mangga dengan berbagai lembaga pemasaran yang dituju di Kecamatan Greged memiliki tenaga kerja $1-2$ orang dari keluarga dan selain keluarga, menerapkan teknologi off-season, pengendalian OPT menggunakan pestisida dan perangkap hama, menerapkan pengaturan waktu tanam, memiliki hasil panen dengan kualitas grade A dan B berkisar 41 -
\end{abstract}


$60 \%$, dan produktivitas per pohonnya $101-300 \mathrm{~kg} /$ pohon. Petani menggunakan lahan kebun usaha dan lahan pekarangan rumah mereka untuk bertanam mangga, kecuali petani yang menjual ke pasar induk hanya menggunakan lahan kebun usaha. Petani yang menjual hasil produksinya ke kelompok tani dan pasar induk tidak melakukan pencucian buah, sedangkan mayoritas petani yang menjual ke tengkulak, bandar, dan pasar tradisional melakukan pencucian buah, sortasi, grading, pengemasan, dan pelabelan.

Kata kunci : Perilaku Budidaya, Lembaga Pemasaran, Petani Mangga

\section{PENDAHULUAN}

Mangga (Mangifera indica L) merupakan salah satu komoditas hortikultura unggulan di Indonesia. Selain karena harga yang terjangkau, buah mangga memiliki nilai ekonomi tinggi dan merupakan bahan makanan penting setelah pisang bagi masyarakat di daerah beriklim tropisjuga menjadi salah satu faktor permintaan dan produksi mangga terus bertambah setiap tahun. Provinsi Jawa Barat memiliki potensi dalam mengembangkan usahatani mangga. Terdapat beberapa kabupaten di Jawa Barat yang menjadi sentra produksi mangga, yaitu Kabupaten Indramayu, Kabupaten Majalengka, Kabupaten Cirebon, dan Kabupaten Kuningan. Kabupaten Cirebon merupakan salah satu sentra produksi mangga di Jawa Barat, dengan produksi yang berfluktuasi. Menurut data BPS, Kabupaten Cirebon mampu memproduksi mangga sebesar 62.053 ton di tahun 2012. Perkembangan produksi mangga di Kabupaten Cirebon dapat dilihat pada grafik berikut.

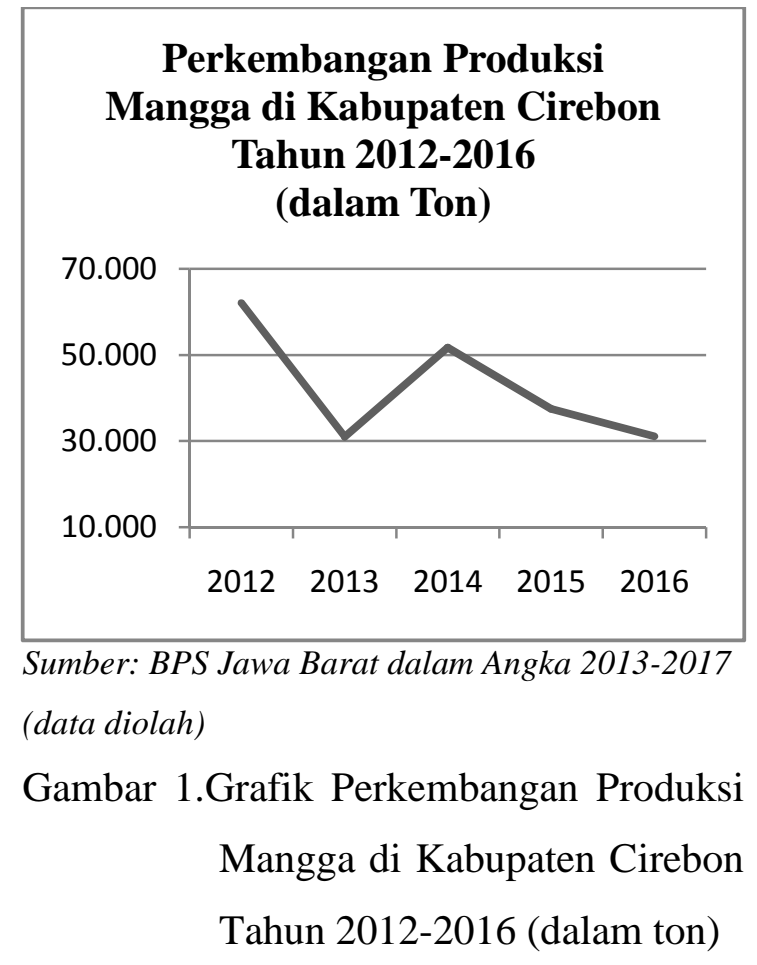

Kecamatan Greged memiliki potensi dalam mengembangkan usahatani mangga di Kabupaten Cirebon. Luas wilayah potensial yang ada di Kecamatan Greged mencapai 1.810 Ha, dengan jumlah tanaman mangga menghasilkan sebanyak 43.744 pohon pada tahun 2014, dan produksi mencapai 1.403 ton pada tahun 2014 (Kabupaten Cirebon dalam Angka 2014). 
Penurunan produksi mangga dapat terjadi karena beberapa faktor, diantaranya iklim atau cuaca yang tidak menentu, serangan hama dan penyakit, penerapan budidaya mangga belum sesuai dengan GAP (Good Agriculture Practice) karena terbatasnya modal petani sehingga input produksi hanya disesuaikan dengan jumlah modal yang dimiliki petani, hingga diduga adanya kesalahan perilaku petani dalam melakukan budidaya mangga yang belum sesuai dengan anjuran. Selain fluktuasinya produksi karena perilaku budidaya petani mangga yang beragam, permasalahan lain yang dihadapi adalah pendistribusian buah mangga oleh petani masih terbatas pada lembaga pemasaran tertentu.

\section{TINJAUAN PUSTAKA}

\section{Perilaku Budidaya Petani Mangga}

\section{Dikaitkan dengan Lembaga Pemasaran}

Perilaku budidaya merupakan cara bertindak petani yang menunjukkan tingkah laku petani dalam melakukan budidaya pertanian (Kast dan Rosensweig, 1995 dalam Fibriz, 2017). Selanjutnya Suyatna (Karunianingtias, 2005) berpendapat bahwa perilaku merupakan hakekat dari tujuan penyuluhan yang mempunyai tiga aspek: pengetahuan (cognitif), sikap (affective) danketerampilan/penerapan. Dalam penelitian ini, perilaku budidaya di Kabupaten Cirebon terdiri dari:
- Karakteristik kebun, meliputi pola tanam, varietas yang ditanam, dan tempat penguasaan lahan

- Tenaga kerja, meliputi jumlah tenaga kerja yang berasal dari keluarga dan selain dari keluarga

- Teknik budidaya, meliputi teknologi off-season, pengendalian OPT, menerapkan pemupukkan yang benar, melakukan pemeliharaan

- Panen dan pascapanen, meliputi penerapan waktu panen, hasil panen dengan kualitas baik, dan kegiatan penanganan pascapanen.

Perilaku budidaya tersebut akan dikaitkan dengan lembaga pemasaran yang dipilih oleh petani dalam memasarkan hasil produksinya. Lembaga pemasaran adalah suatu badan atau individu yang melakukan pemasaran, menyalurkan jasa serta komoditi dari produsen ke konsumen akhir, serta memiliki hubungan dengan badan usaha atau individu lainnya. Dalam penelitian ini, lembaga pemasaran yang terdapat di Kecamatan Greged meliputi kelompok tani, tengkulak, bandar, pasar tradisional, dan pasar induk yang akan dikaitkan dengan perilaku budidaya mulai dari karakteristik kebun, tenaga kerja, teknik budidaya, serta panen dan pasca panen. 


\section{BAHAN DAN METODE}

\section{Objek Penelitian}

Objek dalam penelitian ini adalah perilaku budidaya petani mangga dikaitkan dengan lembaga pemasarannya. Perilaku budidaya meliputi karakteristik kebun, tenaga kerja, teknik budidaya, serta panen dan pascapanen.

\section{Metode Penelitian}

Metode yang digunakan dalam penelitian ini adalah metode survei dengan pengambilan sampel simple random sampling. Responden yang digunakan dalam penelitian ini berjumlah 130 orang petani yang memiliki pengalaman berusahatani mangga minimal 5 tahun.

\section{Teknik Pengumpulan Data}

Pengunpulan data dilakukan dengan menggunakan kuesioner dan wawancara.

\section{HASIL DAN PEMBAHASAN}

\section{Karakteristik Petani Responden}

Karakteristik petani mangga responden berusia berkisar $51-60$ tahun, berpendidikan terakhir SD, memiliki pekerjaan utama sebagai petani mangga, dan memperoleh pendapatan dari berusahatani mangga 10.000.001 50.000.000 per tahun, pengalaman berusahatani mangga $<10$ tahun, hanya memiliki < 0,5 Ha lahan yang diusahakan, dan memiliki $<100$ pohon.

Petani responden di Kecamatan Greged menjual hasil produksi buah mangganya ke berbagai lembaga pemasaran, diantaranya kelompok tani sebanyak $2 \%$ responden, tengkulak $35 \%$ responden, bandar $51 \%$ responden, pasar tradisional 9\% responden, dan pasar induk $3 \%$ responden.

Pada Tabel 1 dapat dilihat bahwa perilaku budidaya dalam penelitian ini terdapat pola tanam, tempat pengusahaan lahan, tenaga kerja, penerapan teknologi off-season, pengendalian OPT, penerapan waktu panen, hasil panen dengan kualitas baik, produktivitas per pohon,dan kegiatan pascapanen. Lembaga pemasaran yang dipilih petani dalam memasarkan hasil panennya meliputi kelompok tani, tengkulak, bandar, pasar tradisional, dan pasar induk.

Mayoritas petani responden memasarkan hasil panennya ke tengkulak dan bandar. Akses yang mudah dari segi persyaratan maupun akses jalan menjadikan petani memilih tengkulak dan bandar sebagai lembaga pemasaran yang mereka tuju. Hanya sedikit petani yang menjual hasil panennya ke kelompok tani, pasar tradisional, maupun pasar induk. Petani yang menjual hasil panennya ke 
kelompok tani merupakan bagian dari kelompok tani itu sendiri, sehingga difasilitasi dalam memasarkan hasil panennya. Sedangkan untuk petani yang memilih pasar tradisional dan pasar induk hanya sedikit dikarenakan jarak yang ditempuh cukup jauh dan memerlukan waktu serta dana lebih untuk mendistribusikannya. Hal itulah yang menjadikan hanya sebagian kecil petani yang memilih pasar tradisional dan pasar induk sebagai lembaga pemasaran yang mereka tuju.

Tabel 1. Perilaku Budidaya Petani Mangga Dikaitkan dengan Lembaga Pemasaran

\begin{tabular}{|c|c|c|c|c|c|c|c|c|}
\hline \multirow[b]{2}{*}{ No } & \multirow{2}{*}{\multicolumn{2}{|c|}{ Perilaku Budidaya Petani Mangga }} & \multicolumn{5}{|c|}{ Lembaga Pemasaran yang Dipilih Petani $(\%)$} & \multirow[b]{2}{*}{$\begin{array}{c}\text { Total } \\
(\%)\end{array}$} \\
\hline & & & $\begin{array}{l}\text { Kelompok } \\
\text { Tani }\end{array}$ & Tengkulak & Bandar & $\begin{array}{c}\text { Pasar } \\
\text { Tradisional }\end{array}$ & $\begin{array}{l}\text { Pasar } \\
\text { Induk }\end{array}$ & \\
\hline \multirow[t]{2}{*}{1.} & Pola Tanam & - Monokultur & 1 & 21 & 31 & 4 & 3 & 60 \\
\hline & & - Polikurtur & 1 & 14 & 20 & 5 & 0 & 40 \\
\hline \multirow[t]{2}{*}{2.} & Tempat & - Kebun Usaha & 1 & 6 & 24 & 7 & 3 & 41 \\
\hline & $\begin{array}{l}\text { Pengusahaan } \\
\text { Lahan }\end{array}$ & \begin{tabular}{|l} 
Kebun Usaha dan \\
Lahan \\
Pekarangan \\
\end{tabular} & 1 & 29 & 27 & 2 & 0 & 59 \\
\hline \multirow[t]{7}{*}{3.} & - Tenaga & -0 & 0 & 3 & 1 & 1 & 0 & 5 \\
\hline & Kerja dari & $-1-2$ orang & 1 & 29 & 45 & 8 & 2 & 86 \\
\hline & Keluarga & $-3-4$ orang & 1 & 2 & 4 & 0 & 1 & 8 \\
\hline & - Tenaga & -0 & 1 & 11 & 15 & 0 & 0 & 27 \\
\hline & Kerja Selain & $-1-2$ orang & 1 & 15 & 25 & 5 & 1 & 47 \\
\hline & Keluarga & $-3-4$ orang & 0 & 8 & 12 & 1 & 1 & 22 \\
\hline & & - $>5$ orang & 0 & 1 & 0 & 2 & 1 & 4 \\
\hline 4. & \multicolumn{2}{|c|}{ Teknologi Off-Season } & 1 & 20 & 33 & 4 & 2 & 60 \\
\hline \multirow[t]{3}{*}{5.} & Pengendalian & - Pestisida & 1 & 15 & 39 & 7 & 2 & 64 \\
\hline & OPT & - Pestisida dan & 1 & 18 & 10 & 2 & 2 & 33 \\
\hline & & $\begin{array}{l}\text { Perangkap Hama } \\
-\quad \text { Lainnya* }\end{array}$ & 0 & 1 & 2 & 0 & 0 & 3 \\
\hline 6. & \multicolumn{2}{|c|}{ Pengaturan Waktu Panen } & 1 & 18 & 35 & 4 & 3 & 61 \\
\hline \multirow[t]{4}{*}{7.} & Hacil Panen & $-\quad<40 \%$ & 1 & 2 & 15 & 0 & 0 & 18 \\
\hline & Hasil Panen & $-\quad 41-60 \%$ & 1 & 5 & 15 & 5 & 1 & 27 \\
\hline & & $-\quad 61-80 \%$ & 0 & 22 & 12 & 3 & 1 & 36 \\
\hline & & $-\quad>81 \%$ & 0 & 5 & 9 & 1 & 1 & 16 \\
\hline \multirow[t]{5}{*}{8.} & & $-\quad<100 \mathrm{Kg}$ & 1 & 5 & 13 & 3 & 1 & 23 \\
\hline & Produktivitas & $-\quad 101-300 \mathrm{Kg}$ & 1 & 22 & 32 & 5 & 2 & 61 \\
\hline & per Pohon & $-\quad 301-500 \mathrm{Kg}$ & 1 & 5 & 1 & 1 & 0 & 8 \\
\hline & & $-\quad 501-700 \mathrm{Kg}$ & 0 & 1 & 1 & 1 & 0 & 3 \\
\hline & & $-\quad>701 \mathrm{Kg}$ & 0 & 1 & 3 & 0 & 0 & 4 \\
\hline \multirow[t]{5}{*}{9.} & Kegiatan & $\begin{array}{ll} & \text { Pencucian Buah }\end{array}$ & 0 & 3 & 1 & 1 & 0 & 4 \\
\hline & Pascapanen & - $\quad$ Sortasi & 2 & 17 & 7 & 1 & 3 & 30 \\
\hline & & - $\quad$ Grading & 1 & 45 & 26 & 22 & 1 & 95 \\
\hline & & - Pengemasan & 1 & 9 & 5 & 1 & 1 & 17 \\
\hline & & - $\quad$ Pelabelan & 0 & 3 & 1 & 1 & 1 & 5 \\
\hline
\end{tabular}

Keterangan: Lainnya*: tidak melakukan pengendalian OPT apapun 
Petani responden di Kecamatan Greged menerapkan 2 jenis pola tanam yaitu monokultur dan polikultur, yang dimana mayoritas petani menetapkan pola tanam polikultur. Pola tanam polikultur ini dibarengi dengan tanaman lain. Mereka menanam tanaman lain untuk dikonsumsi sendiri ataupun untuk dijual lagi. Petani juga menjadikan hasil panen dari tanaman lain tersebut sebagai tambahan pemasukan jika tidak sedang musim panen buah mangga. Tanaman lain yang ditanam oleh petani yang menerapkan pola tanam polikultur diantaranyapadi, ubi, singkong, pisang, jaging, jahe, mentimun, laos, pepaya, pisang, kedongdong, pete, rambutan, sengon, mahoni dan pohon jati.

Sementara itu, berdasarkan data yang ada dapat dilihat bahwa mayoritas petani menanam mangga dengan varietas Gedong Gincu, Cengkir, dan Arumanis. Salah satu varietas yang dijadikan komoditi unggulan oleh pemerintah adalah Gedong Gincu, tetapi petani lebih menyukai varietas Arumanis untuk dibudidayakan. Varietas Arumanis lebih disukai oleh petani dikarenakan rata-rata harga yang diterima tidak jauh berbeda dengan Gedong Gincu, yaitu Arumanis seharga Rp11.500 dan Gedong Gincu Rp13.500 dengan modal yang dikeluarkan untuk varietas Gedong Gincu lebih besar, perawatannya lebih sulit, resiko gagal panen lebih tinggi, dan produktivitasnya tidak sebanyak Arumanis. Jika buah mangga yang dipanen matang dipohon, harga Arumanis yang diterima oleh petani lebih tinggi dibandingkan Gedong Gincu, dengan harga Rp30.000 untuk Arumanis dan Rp22.500 untuk Gedong Gincu. Umumnya, petani responden mendapatkan bibit pohon varietas Gedong Gincu melalui hibah pemerintah dan hanya sebagian kecil yang dibeli sendiri. Bibit pohon varietas lain seperti Arumanis, Gedong Gincu, dan Cengkir didapatkan dengan membeli sendiri atau warisan turunan dari keluarga petani.

Tempat pengusahaan lahan yang petani gunakan merupakan lahan kebun usaha dan lahan pekarangan rumah. Lahan pekarangan rumah digunakan petani untuk menanam pohon mangga dikarenakan untuk memanfaatkan lahan kosong yang mereka punya. Selain itu, jumlah pohon yang petani miliki memang cenderung sedikit sehingga tidak perlu lahan yang luas untuk menanam pohon mangga. Petani yang memilih tengkulak dan bandar sebagai tujuan pasar mereka juga menanam pohon mangga di kebun usaha dan lahan pekarangan rumah, 
begitupun dengan petani yang memilih kelompok tani, pasar tradisional dan pasar induk. Berbeda dengan yang lain, $41 \%$ petani responden yang memilih kelompok tani, pasar tradisional, dan pasar induk, mereka hanya menjadikan kebun usaha sebagai tempat pengusahaan lahan. Hal ini karena jumlah pohon yang dimiliki memang tidak terlalu banyak dan tidak ada rencana untuk menambah pohon mangga, sehingga tidak perlu lahan tambahan untuk menambah pohon mangga mereka.

Tenaga kerja yang petani pekerjakan untuk melakukan usahatani mangga mereka berasal dari keluarga maupun bukan dari keluarga. Rata-rata jumlah tenaga kerja yang petani gunakan hanya 1- 2 orang saja. Hal ini karena pemeliharaan yang dilakukan tidak terlalu banyak, sehingga hanya perlu sedikit tenaga kerja. Tenaga kerja yang berasal bukan dari keluarga juga banyak dimiliki petani. Petani memiliki jumlah tenaga kerja yang tidak terlalu banyak karena juga untuk menghemat biaya. Biaya upah yang petani berikan untuk tenaga kerja bisa mencapai Rp75.000 hingga Rp100.000 perharinya. jika petani dapat meminimalkan tenaga kerja, biaya yang dikeluarkan juga semakin sedikit. Bahkan sebanyak $26 \%$ petani responden tidak memiliki tambahan tenaga kerja dari luar keluarga mereka, karena memang tidak terlalu dibutuhkan. Tetapi $22 \%$ petani lainnya memiliki tenaga kerja selain keluarga sebanyak $3-4$ orang untuk membantu petani dalam melakukan panen dan distribusi buah mangga ke lembaga pemasaran yang dituju, terutama untuk petani yang memilih tengkulak, bandar, dan pasar tradisional.

Rata-rata petani responden sudah menerapkan teknologi off-season, sehingga petani dapat panen dan menjual hasil panen mereka diluar musim panen biasanya. Meskipun sudah menerapkan teknologi off-season, petani juga sering kali masih dihadapi dengan penurunan produksi mangga. Penurunan produksi ini salah satunya disebabkan oleh cuaca dan organisme pengganggu tanaman (OPT). Saat musim hujan tiba, serangan hama dan penyakit lebih sering timbul seperti tumbuhnya jamur pada buah yang menyebabkan buah cepat membusuk dan kulit buah tidak mulus.

Dalam pemeliharaan tanaman mangga, petani melakukan kegiatan penyiraman, pemupukkan, dan pengendalian OPT. Kegiatan penyiraman rutin dilakukan pada saat umur pohon mangga kurang dari 6 tahun, sedangkan untuk pohon mangga yang telah berusia 
lebih dari 6 tahun atau sudah dewasa tidak lagi dilakukan penyiraman secara rutin. Pohon mangga yang berumur lebih dari 6 tahun dapat tetap tumbuh dengan baik meskipun tidak dilakukan penyiraman selama lima bulan, sehingga sebanyak $54 \%$ petani responden hanya mengandalkan air hujan untuk penyiraman. Selain air hujan, petani responden juga menggunakan sumber air lain untuk melakukan penyiraman. $8 \%$ petani responden memanfaatkan sumur bor sebagai sumber air, $19 \%$ petani memanfaatkan air sungai, $13 \%$ petani menggunakan air yang ditampung pada embung, dan $5 \%$ petani lainnya menggunakan hampir semua sumber air yang ada.

Pemupukkan dan pemberian Zat Perangsang Tanaman (ZPT) dilakukan sebanyak 1 sampai 2 kali dalam setahun. Tidak ada dosis pasti pada saat petani memberikan pupuk dan ZPT ke tanaman mangga, petani menggunakan dengan dosis yang sedikit karena keterbatasan modal untuk membeli pupuk. Tetapi sebagian petani justru memberikan pupuk dan ZPT dengan dosis $2-3$ kali lebih banyak dari yang dianjurkan penyuluh, karena mereka beranggapan bahwa semakin banyak pupuk dan ZPT yang diberikan maka hasil produksi akan semakin baik.

Petani melakukan pengendalian denga 2 cara, yaitu menggunakan pestisida dan perangkap hama. Berdasarkan hasil penelitian, petani lebih suka menggunakan pestisida untuk mengendalikan OPT. Pengunaan pestisida dianggap lebih praktis dilakukan dan hasilnya cepat terlihat. Walaupun dengan pemberian pestisida tidak membuat hama hilang sepenuhnya, tetapi hanya berkurang. Pestisida yang petani gunakan cukup mudah ditemuka di toko- toko yang menjual alat pertanian, sehingga pestisida masih menjadi pilihan petani untuk mengendalikan OPT.

Selain pestisida, petani juga menggunakan perangkap hama sebagai alat untuk mengendalikan OPT. Perangkap hama ini didapat petani dari hibah yang diberikan pemerintah. Penggunaan perangkap hama ini dirasa belum efektif bagi petani, karena bila penggunaannya tidak secara serentak, OPT yang ada akan berpindah dari pohon yang dipasang perangkap ke pohon yang tidak dipasang perangkap. Hal ini justru akan merugikan petani yang tidak memasang perangkap karena OPT yang mengganggu pohon mangga mereka akan semakin banyak. Tetapi jika penggunaan 
perangkap hama ini dilakukan secara serentak, dinilai akan banyak mengurangi OPT di pohon mangga.

Umumnya petani mangga memiliki waktu tertentu untuk melakukan panen. Biasanya panen mangga dilakukan 2 tahun sekali, yaitu panen pertama pada bulan Juli - September, dan panen kedua di bulan November Desember. Tetapi karena sudah banyak petani yang menerapkan teknologi offseason, waktu panen dapat dilakukan diluar dari waktu panen yang seharusmya. Pada Tabel 1 dapat dilihat bahwa sebanyak $60 \%$ sudah menerapkan pengaturan waktu panen, yaitu $2-4$ kali dalam setahun. Petani melakukan panen mangga sendiri dan sebagian kecil dari petani yaitu $5 \%$ petani responden, melakukan panen bersama dengan pedagang pengumpul sesuai dengan kesepakatan bersama. Sistem pemanenan yang dilakukan sudah bukan dengan cara tebasan, karena petani merasa bahwa cara tersebut lebih sering membuat petani rugi karena nilai keuntungan hasil produksi tidak dapat di prediksi. Panen dilakukan pada pagi hari untuk menghindari buah terpapar sinar matahari langsung karena kualitas buah menurun. Untuk menghindari buah terkena getah saat pemetikan petani melakukan teknik khusus, yaitu dengan cara memetik buah bersamaan dengan tangkainya, lalu memotong tangkainya dan menghadapkannya ke bawah agar getah tidak mengenai buah. Meskipun begitu, masih sedikit petani yang menggunakan cara tersebut pada saat panen, karena dianggap tidak praktis dan lebih memakan waktu.

Kemampuan petani dalam memproduksi buah dengan grade A dan B terbilang cukup banyak. Sebanyak $36 \%$ responden sudah mampu memproduksi buah dengan grade A dan B sebanyak 61 - $80 \%$ dari total hasil panen mereka. Hal ini cukup baik karena dengan begitu petani juga mendapatkan harga yang lebih tinggi. Meskipun grade yang petani tawarkan cukup baik, mereka tetap memilih tengkulak sebagai lembaga pemasaran yang mereka tuju karena aspek langganan dan merupakan kerabat dekat mereka sendiri. sTetapi tidak sedikit juga petani yang memilih bandar sebagai lembaga pemasaran yang dituju menghasilkan grade A dan B dibawah 40\% dari seluruh hasil panen. Mereka menjual apa adanya ke bandar tersebut. Untuk petani yang memilih pasar tradisional dan pasar induk sebagai lembaga pemasarannya, sudah lebih dari 
$41 \%$ dari seluruh hasil panenya yang memiliki grade A dan $\mathrm{B}$.

Produktivitas per pohon yang petani dapatkan adalah berkisar 101 $300 \mathrm{~kg} /$ pohon. Dengan jumlah produktivitas tersebut, petani sudah dapat memasarkan hasil produksi mangga mereka ke lembaga pemasaran yang mereka tuju sesuai dengan permintaan dan kebutuhan pasar tersebut. Lembaga pemasaran yang masih menjadi pilihan petani dalam memasarkan produk mangganya masih tengkulak dan bandar yang terbanyak. Petani yang memilih kelompok tani sebagai lembaga pemasaran hanya mampu menghasilkan produktivitas buah mangga kurang dari $501 \mathrm{~kg} /$ pohon. Sedangkan petani yang menjual buah mangganya ke pasar tradisional dan pasar induk, produktivitas buah mangganya rata-rata $101-300$ $\mathrm{kg} /$ pohon.

Tabel 1 menunjukkan bahwa mayoritas yang petani lakukan adalah sortasi, grading dan pengemasan. Kegiatan tersebut dilakukan oleh petani dengan berbagai lembaga pemasaran sebagai tujuan pasarnya. Bahkan petani yang menjual hasil panennya ke kelompok tani tidak melakukan pencucian buah, karena memang tidak terlalu diperlukan. Jika dilakukan pencucian buah, buah mangga cenderung lebih mudah busuk dibandingkan dengan yang tidak dicuci. Pencucian buah dapat menurunkan kualitas buah sehingga buah cepat busuk. Buah yang tidak dicuci dan disimpan pada suhu ruangan mulai membusuk pada hari ke-9 setelah panen. Sedangkan untuk buah yang sudah dicuci terlebih dahulu dan disimpan pada suhu ruangan, buah mangga tersebut akan lebih cepat busuk karena biasanya petani mencucinya kurang benar dan tidak dikeringkan dengan benar. Seharusnya pencucian buah dilakukan dengan air yang telah ditambahkan fungisida dan dikeringkan dengan baik, lalu disimpan pada suhu $12-15^{\circ} \mathrm{C}$. Dengan begitu, buah dapat lebih lama disimpan yaitu hingga hari ke-30 setelah panen. Pencucian buah dan pelabelan sangat jarang dilakukan oleh petani karena memang tidak diperlukan dalam memasarkan produk mangga mereka. Karena tujuan lembaga pemasarannya masih banyak yang ke tengkulak dan bandar yang memang menerima buah mangga apa adanya, tidak perlu dilakukan pencucian ataupun pelabelan. Begitupun dengan lembaga pemasaran pasar tradisional dan pasar induk. 


\section{PENUTUP}

\section{Kesimpulan}

Lembaga pemasaran yang dipilih petani yaitu kelompok tani (2\%), tengkulak (35\%), bandar (51\%), pasar tradisional (9\%), dan pasar induk (3\%). Mayoritas petani mangga dengan berbagai lembaga pemasaran yang dituju di Kecamatan Greged memiliki tenaga kerja 1 - 2 orang dari keluarga dan selain keluarga, menerapkan teknologi offseason, pengendalian OPT menggunakan pestisida dan perangkap hama, menerapkan pengaturan waktu tanam, memiliki hasil panen dengan kualitas grade A dan B berkisar $41-60 \%$, dan produktivitas per pohonnya $101-300$ kg/pohon. Petani menggunakan lahan kebun usaha dan lahan pekarangan rumah mereka untuk bertanam mangga, kecuali petani yang menjual ke pasar induk hanya menggunakan lahan kebun usaha. Petani yang menjual hasil produksinya ke kelompok tani dan pasar induk tidak melakukan pencucian buah, sedangkan mayoritas petani yang menjual ke tengkulak, bandar, dan pasar tradisional melakukan pencucian buah, sortasi, grading, pengemasan, dan pelabelan.

\section{Saran}

Petani perlu diberikan pengetahuan dan informasi mengenai pemasaran buah mangga ke berbagai pasar seperti pasar ritel modern dan pasar ekspor oleh lembaga ataupun Dinas Pertanian, sehingga petani dapat memasarkan hasil panen mereka ke pasar-pasar tersebut.Untuk meningkatkan produksi buah mangga dan pendapatan petani dari berusahatani mangga, perlu diadakan penyuluhan atau pelatihan oleh Dinas Pertanian terkait dengan teknik budidaya mangga yang tepat agar kualitas dan kuantitas buah mangga yang dihasilkan dapat terus meningkat.

\section{DAFTAR PUSTAKA}

Anantanyu, Sapja. 2011. Kelembagaan Petani: Peran dan Strategi Pengembangan Kapasitasnya. SEPA : Vol. 7 No.2.

Ardi, Supriyono, Evo Afrianto. 2017. Perilaku Petani Dalam Budidaya Kedelai Di Kecamatan Tebo Ilir Kabupaten Tebo. Jurnal Agri Sains Vol, 1 No.02.

Hanum, Chairani. 2008. Teknik Budidaya Tanaman Jilid 1. Direktorat Pembinaan Sekolah Menengah Kejuruan : Jakarta.

Lestari, V.S et al. 2011. Peranan Beberapa Lembaga Pemasaran dalam Penjualan Telur pada Peternak Ayam Ras Petelur di Indonesia: Studi Kasus di Jawa Barat, Bali Dan Sulawesi Selatan. JITP Vol. 1 No. 2, Januari 2011.

Ramadhani, Widyarina dan Elly Rasmikayati. 2017. Pemilihan Pasar Petani Mangga Serta Dinamika Agribisnisnya di Kecamatan Panyingkiran Kabupaten Majalengka Provinsi Jawa Barat.Jurnal Pemikiran 
Masyarakat Ilmiah Berwawasan Agribisnis, 2017. 3(2): 185-202.

Sisfahyuni, M.S. Saleh dan M.R Yantu. 2011. Kelembagaan Pemasaran Kakao Biji di Tingkat Petani Kabupaten Parigi Moutong Provinsi Sulawesi Tengah. Jurnal Agro Ekonomi, Volume 29 No.2, Oktober 2011 : 191 - 216.
Sulistyowati, Lies, Ronnie S Natawidjaja dan Zumi Saidah. 2013. Faktorfaktor Sosial Ekonomi yang Mempengaruhi Keputusan Petani Mangga Terlibat dalam Sistem Informal dengan Pedagang Pengumpul. Sosiohumaniora, 15(3). 3 November 2013 : 285 293. 